\title{
KARAKTERISASI DAN AKTIVITAS ANTIOKSIDAN SERAT PANGAN DARI TEPUNG KULIT LEMON CUI (Citrus microcarpa)
}

\author{
Oki Oktaviani Dika ${ }^{1}$, Edi Suryanto ${ }^{1}$, Lidya Irma Momuat ${ }^{1}$ \\ Program Studi Kimia Fakultas Matematika dan Ilmu Pengetahuan Alam Universitas Sam Ratulangi Manado \\ Email: okioktavianidika19@gmail.com
}

\begin{abstract}
ABSTRAK
Tujuan dari penelitian ini untuk mengekstraksi dan mengkarakterisasi antioksidan serat pangan dari kulit lemon cui (Citrus microcarpa) dengan perbedaan pelarut menggunakan gelombang ultrasonik. Hasil penelitian menunjukkan bahwa tepung kulit lemon cui yang diekstraksi dengan perbedaan pelarut tidak mengalami perubahan mendasar pada komponen utama ditunjukkan pada hasil spectra Fourier Transfrom Infra Red (FTIR). Karakterisasi secara kimia menunjukkan TPKLC memiliki kandungan air (8,49\%), abu (4,44\%), lemak $(0,8 \%)$, protein $(12,45 \%)$, dan karbohidrat $(73,99 \%)$. AKLC mengandung air $(1,71 \%)$, abu $(4,41 \%)$, lemak $(0,56 \%)$, protein $(10,56 \%)$, karbohidrat $(82,76 \%)$. EKLC mengandung air $(7,88 \%)$, abu $(6,18 \%)$, lemak $(1,04 \%)$, protein $(7,68 \%)$, karbohidrat $(77,22 \%)$. Hasil pengujian aktivitas antioksidan menunjukkan bahwa ekstrak fenolik EKLC (96,48\%) tertinggi diikuti oleh ekstrak fenolik AKLC (95,45\%), dan ekstrak fenolik TPKLC (94,29\%). Hasil penelitian ini menunjukkan bahwa dengan pelarut etanol dapat meningkatkan aktivitas antioksidan dibanding dengan pelarut aquades.
\end{abstract}

Kata kunci: Antioksidan, serat pangan, ekstrak fenolik, tepung kulit lemon cui.

\begin{abstract}
Objective of this study to extract and characterize antioxidant dietary fiber from lemon peel cui (Citrusmicrocarpa)with different solvents using wave ultrasonic. The results showed that the lemon cui peel powder extracted with different solvents did not experience a fundamental change in the main component as shown in the results of the Fourier Transfrom Infra Red (FT-IR) spectra. Chemical characterization showed that TPKLC contained water $(8.49 \%)$, ash $(4.44 \%)$, fat $(0.8 \%)$, protein $(12.45 \%)$, and carbohydrates $(73.99 \%)$. AKLC contains water $(1.71 \%)$, ash $(4.41 \%)$, fat $(0.56 \%)$, protein $(10.56 \%)$, carbohydrates $(82.76 \%)$. EKLC contains water $(7.88 \%)$, ash $(6.18 \%)$, fat $(1.04 \%)$, protein $(7.68 \%)$, carbohydrates $(77.22 \%)$. The results of the antioxidant activity test showed that the highest EKLC phenolic extract $(96.48 \%)$ was followed by AKLC phenolic extract (95.45\%), and TPKLC phenolic extract $(94.29 \%)$. The results of this study indicate that ethanol solvent can increase antioxidant activity compared to distilled water solvent.
\end{abstract}

Key words: Antioxidants, dietary fiber, phenolic extract, lemon cui peel flour.

\section{PENDAHULUAN}

Lemon cui (Citrus microcarpa) merupakan jenis jeruk lokal yang banyak tumbuh di Sulawesi Utara. Lemon cui digunakan oleh masyarakat untuk menghilangkan bau amis pada ikan dan sebagai campuran bumbu masakan pada kuliner tradisonal serta memberi aroma penggugah selera makan. Penggunaan lemon cui dapat menghasilkan limbah berupa kulit karena bagian dari lemon cui yang digunakan hanya air dan daging buah dari hasil pengepresannya sedangkan kulitnya dibuang sebagai limbah oleh masyarakat. Bagian yang dibuang ini berkisar 30\% dari berat total buah dan masih dapat dimanfaatkan sebagai bahan penghasil pektin (Rompas dkk.., 2016). Selain pektin diduga limbah kulit lemon cui mengandung serat pangan dan fitokimia. Beberapa penelitian melaporkan bahwa jeruk yuzu (Citrus junos Sibes.ex), jeruk manis (Citrus sinensis L.), dan jeruk purut (Litrus hystrix DC), memiliki kandungan serat pangan, fenolik, flavonoid (Lagha \& Madania, 2013; Oboh \& Ademosun, 2012; Fridrianny dkk.., 2015).

Kulit jeruk merupakan salah satu limbah organik yang dapat dijadikan sebagai sumber serat pangan yang baik. Bagian-bagian dari serat pangan meliputi hemiselulosa, selulosa, dan lignin yang tidak dapat dicerna oleh usus halus manusia namun mengalami fermentasi di usus besar. Serat pangan memiliki manfaat bagi kesehatan seperti penanggulangan 
penyakit diabetes dan hipertensi, pencegahan gangguan gastrointestinal, dan kanker kolon (Santoso, 2011).

Pada tahun terakhir ini, teknik ultrasonikasi telah digunakan secara luas untuk ekstraksi senyawa aktif (Suryanto, 2020). Ekstraksi ultasonik dapat dijadikan metode alternative. Reactor ultrasonik mengandung gelombang ultrasonik yang digunakan untuk membuat gelembung kavitasi (cavitation bubbles) pada material larutan. Ketika gelembung dekat dengan dinding sel maka akan terbentuk gelombang dan pancaran cairan (liquid jets) yang akan membuat dinding sel pecah. Pecahnya dinding sel akan membuat komponen di dalam sel keluar bercampur dengan larutan. Cara ekstraksi ini biasanya lebih cepat dan lebih efisien dibandingkan dengan cara-cara ekstraksi yang terdahulu (Cintas \& Cravotto, 2005).

Berdasarkan uraian di atas, penelitian mengenai serat pangan yang mengandung antioksidan dari kulit lemon cui belum banyak dilakukan. Oleh karena itu, peneliti tertarik untuk mempelajari karakteristik fisikokimia dengan perlakuan ekstraksi menggunakan gelombang ultrasonik dengan pelarut aquades dan etanol serta aktivitas antioksidan serat pangan dari kulit lemon cui.

\section{BAHAN DAN METODE}

Bahan yang digunakan dalam penelitian yaitu kulit lemon cui yang diperoleh dari rumah makan di Manado. Beberapa bahan kimia yang digunakan adalah etanol, aseton, reagen Folin-Ciocalteu, natrium karbonat, asam klorida, asam sulfat, natrium hidroksida dan natrium nitrit diperoleh dari Merck (Germany, Damstadt). 1,1-difenil-2-pikrilhidrazil (DPPH), asam sulfanilat $\quad 0,4 \%, \quad \mathrm{~N}-(1-\mathrm{Naphthyl})$ ethylenediamine, enzim $\alpha$-amilase dan enzim amiloglukosidase diperoleh dari SigmaAldrich.

\section{Preparasi sampel}

Kulit lemon cui dipisahkan antara kulit dan daging. Kulit lemon cui yang diperoleh direbus selama 1 jam dan dipotong-potong menjadi ukuran kecil. Kulit lemon cui yang diperoleh dikeringkan dalam oven pada suhu $50-60{ }^{\circ} \mathrm{C}$ selama 24 jam dan dihaluskan menjadi bubuk kasar menggunakan blender. Setelah itu bubuk kasar di ayak dengan ayakan 30 mesh.
Sampel kulit lemon cui yang lolos dari ayakan kemudian dihaluskan menggunakan alat milling (Formac tipe FCT-Z200, frekuensi $50-60 \mathrm{~Hz}$ dan $28.000 \mathrm{rpm}$ ) dan diayak menggunakan ayakan 200 mesh $(75 \mu \mathrm{m})$. Sebanyak $20 \mathrm{~g}$ tepung kulit lemon cui disoxhletasi dengan 300 $\mathrm{mL}$ petroleum eter untuk memisahkan minyak atsiri, lemak dan oleoresin. Setelah itu tepung yang diperoleh dikering anginkan dan disimpan dalam wadah kedap udara.

\section{Ekstraksi tepung kulit lemon cui}

Tepung kulit lemon cui (200 mesh) diekstraksi menggunakan teknik ekstraksi sonikasi (Krisbow, frekuensi $37 \mathrm{kHz}$, daya 50 watt) dengan pelarut etanol $80 \%$ dan akuades. Masing-masing sebanyak $5 \mathrm{~g}$ tepung kulit lemon cui dimasukkan ke dalam gelas piala dan ditambahkan pelarut kemudian disonikasi selama 180 menit pada suhu kamar, setelah disonikasi sampel disaring sehingga diperoleh filtrat dan residu. Residu kemudian dikeringkan pada suhu $50-60{ }^{\circ} \mathrm{C}$. Residu yang telah kering selanjutnya kembali di milling sehingga diperoleh tepung serat pangan.

\section{Karakteristik fisik}

Tepung kulit lemon cui di karakterisasi secara fisik menggunakan Fourier Transform Infra Red (FT-IR, Shimadzu 180, Japan) untuk mengetahui gugus fungsi.

\section{Karakteristik kimia}

Karakterisasi kimia tepung kulit lemon cui meliputi proksimat, penentuan serat pangan, penentuan kadar hemiselulosa, selulosa, dan lignin.

\section{Ekstraksi fitokimia}

Sebanyak 0,5 g tepung kulit lemon cui hasil ekstraksi etanol $80 \%$ dan akuades dilarutkan kembali dengan $10 \mathrm{~mL}$ etanol $80 \%$ kemudian diekstraksi menggunakan teknik ekstraksi sonikasi selama 30 menit. Selanjutnya, disaring menggunakan kertas saring sehingga diperoleh filtrat dan residu. Selanjutnya, residu ditambahkan etanol $80 \%$ dan disonikasi selama 30 menit setelah itu disaring. Filtrat hasil sonikasi yang pertama dan kedua digabungkan kemudian dievaporasi pada suhu 40-50 ${ }^{\circ} \mathrm{C}$. ekstrak yang diperoleh ditimbang dan disimpan pada suhu $0{ }^{\circ} \mathrm{C}$ sebelum dianalisis kandungan total fenolik, aktivitas antioksidan, dan kapasitas penangkal ion nitrit. 


\section{Penentuan kandungan total fenolik}

Kandungan total fenolik ditentukan menggunakan metode Jeong dkk.. (2004). Sebanyak $0,1 \quad \mathrm{~mL}$ sampel $1000 \mu \mathrm{g} / \mathrm{mL}$ dimasukkan ke dalam tabung reaksi, lalu ditambahkan $0,1 \mathrm{~mL}$ reagen Folin Ciocalteu $50 \%$ kemudian campuran divortex selama 3 menit. Setelah interval waktu 3 menit, ditambahkan $2 \mathrm{~mL}$ larutan $\mathrm{Na}_{2} \mathrm{CO}_{3} \quad 2 \%$, kemudian diinkubasi dalam ruang gelap selama 30 menit. Selanjutnya dibaca absorbansinya pada $\lambda \quad 750 \mathrm{~nm}$ dengan menggunakan spektrofotometer UV-Vis.

\section{Penentuan aktivitas penangkal radikal bebas DPPH}

Penentuan aktivitas penangkal radikal bebas serbuk halus kulit lemon cui ditentukan dengan metode Burda \& Oleszek (2001). Sebanyak 0,5 mL masing-masing ekstrak ditambahkan dengan 1,5 mL larutan DPPH dan divortex selama 2 menit. Berubahnya warna

\section{Kandungan serat pangan}

Serat pangan merupakan karbohidrat yang tidak dapat dicerna oleh enzim- enzim pada pencernaan manusia dan akhirnya sampai di usus besar seperti selulosa, hemiselulosa, pektin, lignin, gum, muscilage. Serat pangan dapat digolongkan menjadi serat pangan terlarut (soluble fiber) dan serat pangan tak larut (insoluble fiber). Contoh serat tidak larut larutan dari ungu kekuning menunjukan efisiensi penangkal radikal bebas. Selanjutnya pada 5 menit terakhir menjelang 30 menit inkubasi, absorbansinya diukur pada $\lambda 517 \mathrm{~nm}$ dengan menggunakan spektrofotometer UVVIS.

\section{Kapasitas penangkal ion nitrit}

Kapasitas penangkal ion nitrit ditentukan menggunakan metode Zhang dkk. (2009). $2 \mathrm{~mL}$ natrium nitrit $5 \mathrm{mg} / \mathrm{L}$ dicampur dengan $3 \mathrm{~mL}$ ekstrak dalam labu $25 \mathrm{~mL}$ pada suhu kamar selama 30 menit. Larutan campuran dicampur dengan $1 \mathrm{~mL}$ asam sulfanilat $0,4 \%$ distirer selama 5 menit diikuti penambahan 0,5 $\mathrm{mL} N$-(1-Naphtly)ethylenediamine $0,1 \%$ dan volume disesuaikan menjadi $25 \mathrm{~mL}$ dengan akuades. Larutan didiamkan selama 15 menit dan diukur absorbansinya menggunakan Spektrofotometer UV-Vis pada $\lambda 538 \mathrm{~nm}$.

\section{HASIL DAN PEMBAHASAN}

adalah selulosa, hemiselulosa dan lignin yang ada dalam serealia, kacang-kacangan dan sayuran. Serat pangan terlarut seperti gum, pektin dan muscilage (Susilowati, 2010). Kandungan serat pangan dari kulit lemon cui yang diekstraksi dengan aquades dan etanol yang merupakan rata-rata dari hasil dua kali pengulangan diperlihatkan pada Tabel 1.

Tabel 1. Hasil analisis serat pangan tepung kulit lemon cui

\begin{tabular}{lccr}
\hline \multirow{2}{*}{ Serat pangan } & \multicolumn{3}{c}{ Sampel } \\
\cline { 2 - 4 } & TPKLC & AKLC & EKLC \\
\hline Tak larut (\%) & $47,71 \pm 0,12^{\mathrm{b}}$ & $47,35 \pm 0,11^{\mathrm{b}}$ & $48,22 \pm 0,17^{\mathrm{a}}$ \\
Larut (\%) & $1,70 \pm 0,01^{\mathrm{b}}$ & $1,98 \pm 0,01^{\mathrm{a}}$ & $1,88 \pm 0,08^{\mathrm{a}}$ \\
Total (\%) & $49,42 \pm 0,13^{\mathrm{a}}$ & $49,33 \pm 0,12^{\mathrm{a}}$ & $49,85 \pm 0,61^{\mathrm{a}}$ \\
\hline
\end{tabular}

Keterangan: TPKLC $=$ Kulit lemon cui yang tanpa perlakuan; AKLC $=$ Kulit lemon cui yang diekstraksi dengan aquades; EKLC $=$ Kulit lemon cui yang diekstraksi dengan etanol. Huruf yang berbeda dibelakang angka menunjukkan perbedaan signifikansi.

Berdasarkan Tabel 3, kandungan serat pangan total pada TPKLC sebesar $49,42 \%$ yang terdiri dari serat pangan tak larut $47,71 \%$ dan serat pangan terlarut $1,70 \%$ sedangkan dengan pelarut aquades (AKLC) sebesar $49,33 \%$ yang terdiri dari serat pangan tak larut $47,35 \%$ dan serat pangan terlarut $1,98 \%$, dan dengan pelarut etanol (EKLC) sebesar 49,85\% yang terdiri dari serat pangan tak larut $48,22 \%$ dan serat pangan terlarut $1,88 \%$. Hasil analisis statistik menujukkan masingmasing jenis perlakuan pada sampel berpengaruh nyata terhadap kadar serat tak larut. Sedangkan pada serat terlarut, jenis pelarut yang digunakan tidak berpengaruh nyata terhadap komponen serat pangan terlarut. 
Kandungan serat pangan pada EKLC lebih tinggi dari pada TPKLC. Tingginya serat pangan pada EKLC mungkin disebabkan oleh lebih banyaknya komponen karbohidrat yang ikut terekstrak oleh pelarut etanol sehingga nilai TPKLC lebih rendah daripada EKLC. Karbohidrat memiliki sifat yang mudah larut dalam pelarut polar dan kurang larut dalam pelarut non-polar (Stryer, 2000).

Kandungan hemiselulosa, selulosa, dan lignin

Hemiselulosa, selulosa dan lignin merupakan komponen serat pangan yang tidak dapat terhidrolisis oleh enzim pencernaan manusia. Selulosa adalah polimer glukosa yang berbentuk rantai linier dan dihubungkan oleh ikatan $\beta-1,4$ glikosidik (Perez dkk.., 2002). Hemiselulosa merupakan polisakarida yang terdiri atas glukosa, xilosa, manosa dan asam glukoronat sedangkan lignin adalah polimer aromatik dengan berat molekul besar yang diklasifikasikan sebagai serat pangan karena mudah dicerna (Sumitro dkk., 2017). Hasil analisis kandungan hemiselulosa, selulosa dan lignin dari tepung kulit lemon cui ditunjukkan pada Tabel 2.

Tabel 2. Kandungan hemiselulosa, selulosa dan lignin tepung kulit lemon cui

\begin{tabular}{lccc}
\hline \multirow{2}{*}{ Kandungan } & \multicolumn{3}{c}{ Sampel } \\
\cline { 2 - 4 } & TPKLC & AKLC & EKLC \\
\hline Hemiselulosa (\%) & $28,63 \pm 0,22^{\mathrm{b}}$ & $28,72 \pm 0,30^{\mathrm{b}}$ & $32,71 \pm 0,13^{\mathrm{a}}$ \\
Selulosa (\%) & $11,18 \pm 0,11^{\mathrm{c}}$ & $14,69 \pm 0,01^{\mathrm{b}}$ & $15,12 \pm 0,06^{\mathrm{a}}$ \\
Lignin (\%) & $12,16 \pm 0,02^{\mathrm{b}}$ & $12,86 \pm 0,20^{\mathrm{a}}$ & $9,56 \pm 0,11^{\mathrm{c}}$ \\
\hline
\end{tabular}

Singkatan seperti yang terdapat pada Tabel 1

Berdasarkan Tabel 2, diperoleh kandungan hemiselulosa, selulosa dan lignin pada EKLC secara berturut-turut adalah $32,16 \%, 15,12 \%, 9,56 \%$ pada AKLC $28,72 \%$, $14,69 \%, 12,86 \%$ dan pada TPKLC $28,63 \%$, $11,18 \%, 12,16 \%$. Hasil menunjukkan tepung kulit lemon cui EKLC memiliki kandungan hemiselulosa dan selulosa yang lebih tinggi dari pada TPKLC dan AKLC. sedangkan komponen lignin ditemukan paling tinggi pada AKLC.

\section{Spektra IR}

Spektrofotometri FT-IR (Fourier Transform Infra-Red) digunakan untuk melihat perubahan pada komposisi kimia serat pangan tepung kulit lemon cui yang dihasilkan dari berbagai perlakuan yang berbeda. Dalam penelitian ini dilakukan analisis spektrofotometer FT-IR pada tepung kulit lemon cui setelah disonikasi dengan masing-masing pelarut aquades dan etanol dan dibandingkan dengan spektrum mikrokristalin selulosa (SMK) sebagai standar. Spektra FT-IR dari TPKLC, AKLC, EKLC dan SMK disajikan pada Gambar 1. 

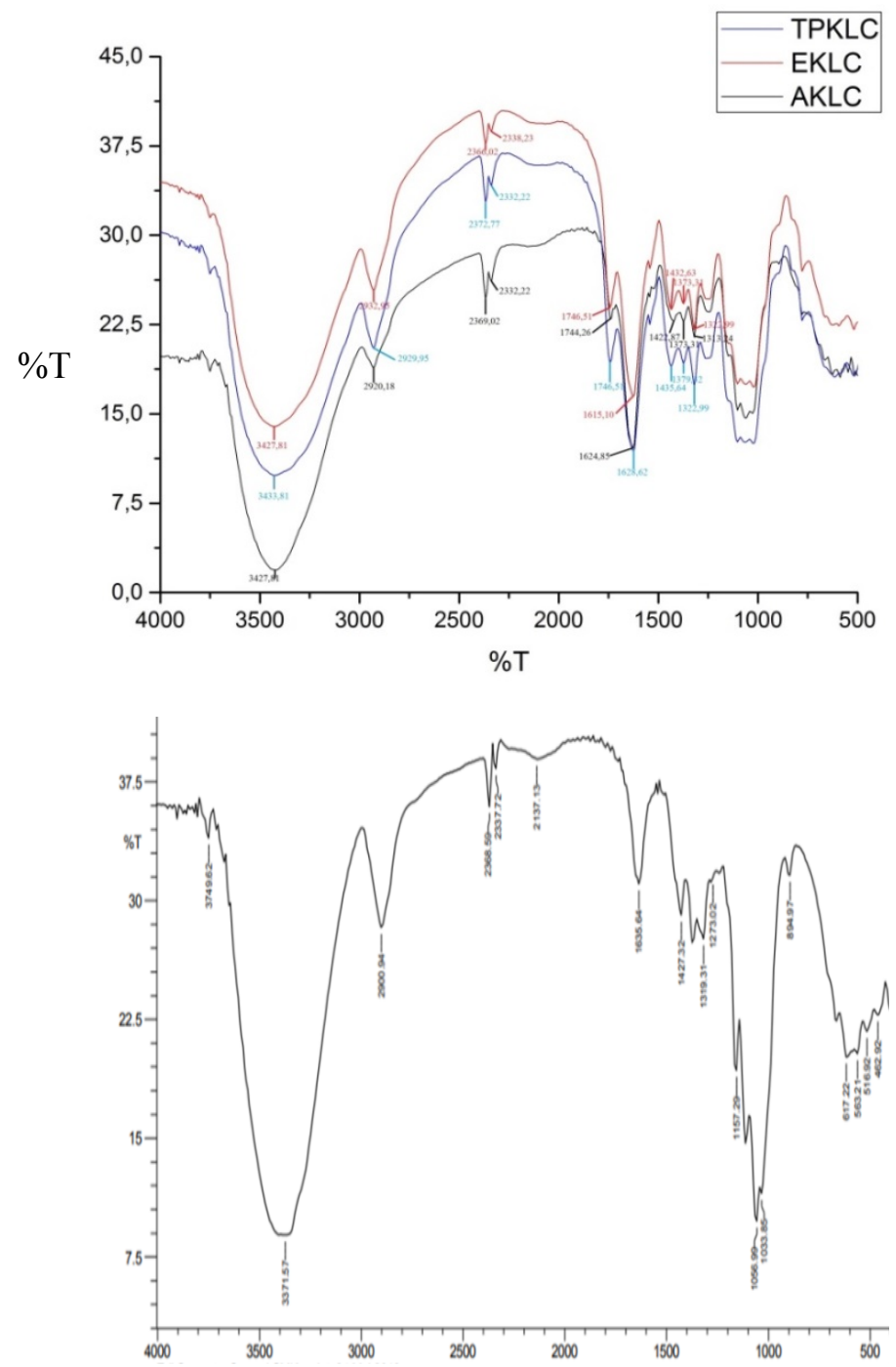

Gambar 1. Profil spektra FT-IR dari TPKLC, AKLC, EKLC dan mikrokristalin selulosa Art. 2330 (Merck) (SMK).

Berdasarkan Gambar 1, spektra dari standar selulosa menunjukkan adanya serapan pada bilangan gelombang $3371.57 \mathrm{~cm}^{-1}$, sedangkan pada spektra dari TPKLC, AKLC, dan EKLC berturut-turut muncul pada bilangan gelombang $3433,81 \mathrm{~cm}^{-1}$ dan $3427,81 \mathrm{~cm}^{-1}$ yang mana daerah serapan $3433 \mathrm{~cm}^{-1}$ merupakan vibrasi $\mathrm{H}-\mathrm{O}-\mathrm{H}$ yang membentuk ikatan hidrogen dengan air (Katti, 2001), sedangkan 3421-3428 $\mathrm{cm}^{-1}$ mengindikasikan adanya renggangan $\mathrm{OH}$ dari gugus hidroksil yang berasal dari selulosa (Milovanovic dkk.., 2016). Spektra dari selulosa standar menunjukkan

\section{Rendemen dan ekstraksi}

Metode ekstraksi yang dilakukan dalam penelitian ini adalah ekstraksi dengan menggunakan gelombang ultrasonik. Ekstraksi serapan pada bilangan gelombang $2900.94 \mathrm{~cm}^{-1}$ sedangkan spektra dari EKLC, TPKLC, dan AKLC menunjukkan serapan pada bilangan gelombang $2920,18 \mathrm{~cm}^{-1}, 2929,95 \mathrm{~cm}^{-1}, 2932,95$ $\mathrm{cm}^{-1}$ yang mana daerah serapan $3000-2840 \mathrm{~cm}^{-1}$ menunjukkan vibrasi C-H dari selulosa yang mengindikasikan kehadiran senyawa polisakarida (Abbasi dkk., 2016). Menurut Ma \& Mu (2016), karakteristik puncak pada $1744 \mathrm{~cm}^{-1}$ berhubungan dengan getaran regangan gugus karbonil dari gugus ester yang sesuai pada serapan bilangan AKLC.

TPKLC, AKLC dan EKLC dengan pelarut etanol digunakan untuk mendapatkan ekstrak fenolik. Hasil rendemen dari metode ekstraksi tersebut dari TPKLC, AKLC, dan EKLC dapat 
dilihat pada Tabel 4.

Tabel 4. Rendemen ekstraksi masing-masing ekstrak

\begin{tabular}{cc}
\hline Sampel & Rendemen (\%) \\
\hline TPKLC & 74,65 \\
AKLC & 85,08 \\
EKLC & 77,35 \\
\hline
\end{tabular}

Singkatan seperti yang terdapat pada Tabel 1

Dari data yang dapat dilihat pada Tabel 4, dapat diketahui bahwa AKLC memperoleh presentase rendemen yang lebih tinggi dari pada EKLC dan TPKLC. Tingginya nilai rendemen AKLC mengindikasikan bahwa kulit lemon cui memiliki banyak komponen senyawa metabolit sekunder yang tidak terekstraksi hanya dengan metode ekstraksi maserasi. Pelarut yang digunakan dalam penelitian ini adalah pelarut etanol 80\% karena pelarut ini bersifat polar, universal dan food grade. Pelarut polar yang digunakan bertujuan untuk mengambil komponen polar seperti senyawa fenolik.

\section{Kandungan total fenolik}

Hasil analisis kandungan fenolik tepung kulit lemon cui ditunjukkan pada Tabel 5 . Berdasarkan Tabel 5 dapat diketahui bahwa kandungan fenolik tertinggi terdapat pada ekstrak fenolik TPKLC sebesar 79,92 $\mu \mathrm{g} / \mathrm{mL}$, diikuti ekstrak fenolik AKLC $62,54 \mu \mathrm{g} / \mathrm{mL}$, dan yang terakhir yaitu ekstrak fenolik EKLC 45,66 $\mu \mathrm{g} / \mathrm{mL}$. Hasil uji statistik menunjukkan bahwa terdapat perbedaan nyata dari masing-masing ekstrak $(p<0,05)$ terhadap kandungan fenolik. Total fenolik dari TPKLC lebih tinggi daripada EKLC. Hal ini diduga karena senyawa dalam ekstrak TPKLC masih utuh karena tidak melawati sonikasi selama 3 jam sehingga mempengaruhi ikatan hidrogen antara molekul karbohidrat dengan senyawa fenolik dalam tepung kulit lemon cui membuat senyawa fenolik lebih mudah diekstrak.

Tabel 5. Kandungan total fenolik dari ekstrak $1000 \mu \mathrm{g} / \mathrm{mL}$ TPKLC, AKLC dan EKLC

\begin{tabular}{lc}
\hline \multicolumn{1}{c}{ Sampel } & Total fenolik $(\mu \mathrm{g} / \mathrm{mL})$ \\
\hline TPKLC & $79,92 \pm 0,35^{\mathrm{a}}$ \\
AKLC & $62,54 \pm 0,12^{\mathrm{b}}$ \\
EKLC & $45,66 \pm 2,43^{\mathrm{c}}$ \\
\hline
\end{tabular}

Singkatan seperti yang terdapat pada Tabel 1

EKLC yang telah diekstraksi dengan pelarut etanol selama 30 menit memiliki kandungan fenolik yang paling rendah. Itu kemungkinan terjadi karena senyawa pada ekstrak fenolik EKLC sudah menyusut dikarenakan pengaruh dari sonikasi selama 3 jam.

\section{Kemampuan penangkal radikal bebas}

Hasil pengujian kemampuan penangkal radikal bebas DPPH dari ekstrak TPKLC, AKLC, dan EKLC konsentrasi $1000 \mu \mathrm{g} / \mathrm{mL}$ dapat dilihat pada Tabel 6 . 
Tabel 6. Aktivitas penangkal radikal bebas dari berbagai ekstrak TPKLC,AKLC dan EKLC

\begin{tabular}{cc}
\hline Sampel & Aktivitas penangkal radikal bebas (\%) \\
\hline Ekstrak TPKLC & $94,29 \pm 0,35^{\mathrm{b}}$ \\
Ekstrak AKLC & $95,45 \pm 0,35^{\mathrm{ab}}$ \\
Ekstrak EKLC & $96,48 \pm 0,11^{\mathrm{a}}$ \\
\hline
\end{tabular}

Singkatan seperti yang terdapat pada Tabel 1

Berdasarkan Tabel 6. ekstrak fenolik EKLC memberi hasil paling tinggi yaitu 96,48\% diikuti oleh ekstrak fenolik AKLC 94,45\%. Hasil uji statistik menunjukkan terdapat pengaruh nyata dari ekstrak fenolik EKLC terhadap aktivitas penangkal radikal bebas. Sedangkan fenolik TPKLC tidak berpengaruh nyata terhadap aktivitas antioksidan. Ekstrak fenolik EKLC menunjukkan aktivitas penangkal radikal bebas yang paling tinggi. Tingginya aktivitas antioksidan ekstrak EKLC menandakan bahwa ekstrak kulit lemon cui dengan pelarut etanol mengandung senyawa-senyawa bioaktif yang dapat berfungsi sebagai antioksidan yang lebih baik, jika dibandingkan ekstrak kulit lemon cui dengan pelarut lainnya, sehingga lebih efektif dalam penghambatan radikal bebas DPPH.

\section{Kapasitas penangkal ion nitrit}

Hasil analisis kapasitas penangkal nitrit dari ekstrak fenolik tepung kulit lemon cui masing-masing disajikan pada Tabel 7.

Tabel 7. Kapasitas penangkal nitrit dari berbagai ekstrak tepung kulit lemon cui

\begin{tabular}{cc}
\hline Sampel & Kapasitas penangkal nitrit (\%) \\
\hline TPKLC & $52,64 \pm 4,15^{\mathrm{a}}$ \\
AKLC & $52,54 \pm 2,77^{\mathrm{a}}$ \\
EKLC & $53,13 \pm 0,69^{\mathrm{a}}$ \\
\hline
\end{tabular}

Singkatan seperti yang terdapat pada Tabel 1

Berdasarkan Tabel 7, kapasitas penangkal nitrit (KPN) ekstrak fenolik EKLC $53,13 \%$, TPKLC 52,64\%, dan AKLC 52,54\%. Hasil analisis menunjukkan ekstrak fenolik EKLC memiliki KPN lebih tinggi dari pada ekstrak fenolik AKLC. Rendahnya KPN ekstrak fenolik AKLC kemungkinan karena adanya senyawa fenolik pada ekstrak yang bersifat prooksidan berinteraksi dengan radikal nitrit mempercepat proses oksidasi lipid. Prooksidan merupakan sifat senyawa yang dapat mendorong oksidasi pada komponen sel yang melibatkan senyawa radikal bebas (Skrzdlewska dkk.., 2004). Senyawa prooksidan ini menimbulkan radikal bebas yang mendorong terjadinya peroksidasi lipid.

\section{KESIMPULAN}

Pengujian kandungan total fenolik menunjukkan bahwa ekstrak fenolik dari TPKLC, lebih tinggi dibandingkan ekstrak fenolik AKLC dan EKLC. Untuk aktivitas penangkal radikal bebas tertinggi diperoleh ekstrak fenolik dari EKLC sedangkan untuk penangkalan nitrit tertinggi diperoleh ekstrak fenolik dari EKLC.

\section{DAFTAR PUSTAKA}

Burda, S.W. \& Oleszek. 2001. Antioxidant and antiradical activities of flavonoids. Journal of Agriculcure and Food Chemistry. 49(6), 2774-2779.

Cintas, P. \& Cravotto, G. 2005. Power ultrasound in organic synthesis: moving 
cavitational chemistry from academia to innovative and large-scale applications. The Royal Society Journal of Chemistry. 35(2), 80-196.

Fidrianny, I., Johan, Y. \& Sukrasno. 2015. Antioxidant activities of different polarity extracts from three organs of makrut lime (Citrus Hystrix Dc) and correlation with total flavonoid, phenolic, carotenoid content. Asian Journal of Pharmaceutical and Clinical Reserch. 8(4): 239-243.

Jeong, S.M., Kim, S.Y., Kim, D.R., Jo, S.C., Nam, K.C., Ahn, D.U. \& Lee, S.C. 2004. Effect of heat treatment onthe antioxidant activity of extracts from citrus peels. Journal of Agricultural and Food Chemistry. 52(11), 3389-3393.

Lagha-Benamrouche, S., Madanai, K. 2013. Phenolic contents and antioxidant activity of citrus varieties (Citrus sinensis L. and Citrus aurantium L.) cultivated in Algeria: peals and leaves. Ind. Crops Prod. 50(7), 723-730

Liu, Y., Wang, L., Liu, F. \& Pan, S. 2016. Effect grinding methods on structural, physicochemical, and functional properties of insoluble dietary fiber from orange peel. International Journal of Polymer Science. 2016(2), 1-7.

Ma, M. \& Mu, T. 2016. Modification of deoiled cumin dietary fiber with laccase and cellulase under high hidrostatic pressure. Carbohidrate Polimers. 136(9), 87-94.

Milovanovic, S., Markovic, D., Aksentijevic, K., Stojanovic, D.B., Ivanovic, J. \& Zizovic, I. 2016. Application of cellulose acetate for controlled release of thymol. Carbohydrate Polymers. 147 (1), 344-353.
Oboh, G. \& Ademosun, A.O. 2012. Characterization of the antioksidant properties of phenolic extracts from some citrus peels. Journal of Food Science and Technology. 49(6), 729-736.

Perez, J. Dorado. 2002. Biodegradation and biological treatments of cellulose, hemicellulose and lignin. An overview. International Journal of Microbiology. $5(2), 53-63$

Rompas, V.F., Mamuaja, C.F. \& Suryanto, E. 2016. Ekstraksi pektin dari lemon cui (Citrus microcarpa Bunge) dan aplikasinya pada pembuatan selai nenas. Jurnal Ilmu dan Teknologi Pangan. 4(2), 30.

Santoso, A. 2011. Serat pangan (dietary fiber) dan manfaatnya bagi kesehatan. Magistra. 23(75), 35-40.

Skrzydlewska, E., Ostrowska, J., Luczaj, W., Kasacka, I. \& Rozanski, A. 2004. Green Tea Against Ethanol-Induced Lipid Peroksidasi In Rat Organs. Journal of Clinical Medicine. 32(1), 25-32.

Stryer, L. 2000. Biokimia Edisi 4 Volume 1. EGC, Jakarta.

Sumitro, S.B., Sri, W. \& Sofy. 2017. Biologi Sel : Sebuah Perspektif Memahami Sistem Kehidupan. UB Press, Malang.

Suryanto, E \& Suoth, E.J. 2020. Fitokimia II. CV. Patra Media Grafindo. Bandung.

Suryanto, H. 2017. Analisis struktur serat selulosa dari bakteri. Prosiding Seminar Nasional Teknologi Terapan. 3(1), 17-22.

Zhang, L.,Xu,H. \& Li, S. 2009. Effects of micronization on properties of chzenomeles sintesis (Thouin) Koehne fruit powder. Innovative Food Science \& Emerging Technologies. 10(4), 633-639. 